\title{
Polytherapy with Reserpine and Glucagon-like Peptide-1 (GLP-1) Improves the Symptoms in Streptozotocin-Induced Type-1 Diabetic Mice by Reducing Inflammation and Inducting Beta Cell Regeneration
}

Evgenii Germanovich Skurikhin ${ }^{1}$, Olga Victorovna Pershina ${ }^{1 *}$, Natalia Nikolaevna Ermakova ${ }^{1}$, Lubov Alexandrovna Ermolaeva ${ }^{1}$, Vyacheslav $^{2}$ Andreevich Krupin ${ }^{1}$, Angelina Vladimirovna Pakhomova', Edgar Sergeevich Pan ${ }^{1}$, Marie-Theres Zeuner ${ }^{2}$, Darius Widera ${ }^{2}$, Ekaterina Sergeevna Khmelevskaya ${ }^{1}$, Vladimir Petrovich Fisenko ${ }^{3}$ and Alexander Mikhaylovich Dygai ${ }^{1}$

${ }^{1}$ Laboratory of Regenerative Pharmacology, Goldberg ED Research Institute of Pharmacology and Regenerative Medicine, Tomsk National Research Medical Centre of the Russian Academy of Sciences, Tomsk, Russia

${ }^{2}$ Stem Cell Biology and Regenerative Medicine Group, Department of Pharmacology, School of Pharmacy, University of Reading, Reading, United Kingdom ${ }^{3}$ Department of Pharmacology, Sechenov First State Medical University, Russia

\begin{abstract}
The present study investigated the effects of a polytherapy with Glucagon-like Peptide-1 (GLP-1) and the Vesicular Monoamine Transporter (VMAT) inhibitor reserpine on Streptozotocin (STZ)-induced type 1 diabetic mice.

Methods: Experimental diabetes was induced in C57BL/6 mice by STZ. Reserpine and GLP-1 were applied intraperitoneally as poly- or monotherapy.

Results and Conclusion: We show for the first time that reserpine/GLP-1 polytherapy has a hypoglycaemic effect and increases the concentrations of insulin and GLP-1, reduces the level of IL-1 $\beta$ in the serum and infiltration of inflammatory cells into the pancreas, led to an increased number of multipotent beta cell progenitors, oligopotent beta cell precursors and Pdx1+ beta cells. We observed increased regeneration of beta cells in the diabetic pancreas. Hence, our approach could pave the way for developing new therapy approaches for Type 1 Diabetes (T1D).
\end{abstract}

Keywords: Reserpine; Glucagon-like peptide-1; Type 1 diabetes; Regeneration; Inflammation

Abbreviations: GLP-1: Glucagon-like Peptide-1; VMAT: Vesicular Monoamine Transporter; STZ: Streptozotocin; T1D: Type 1 Diabetes; SCs: Stem Cells; IL: Interleukin; GPCRs: G Protein-Coupled Receptors; HSCs: Haematopoietic Stem Cells; SNS: Sympathetic Nervous System; HPCs: Haematopoietic Progenitor Cells; PBS: Phosphate-Buffered Saline.

\section{Introduction}

Diabetes is a complex metabolic disorder resulting from abnormally high blood glucose levels (Hyperglycemia) mainly caused by insulin insufficiency, insulin dysfunction and/or loss of insulin-producing pancreatic beta cells [1,2]. Maintenance of a healthy blood glucose level can be achieved by regular injections of exogenous insulin in patients suffering from T1D, reducing the risk of various diabetic complications, including nephropathy and neuropathy. However, achieving long-term glucose levels within a narrow physiological range by regular insulin injections is still impossible. Thus, beta cell pool recovery is still one of the primary goals in treatment of diabetes. Addressing this, pancreas and pancreatic islets transplantation were considered as potential therapeutic options [3]. However, a chronic shortage of donor organs and the need for concomitant immunosuppressive therapy restrict the widespread use of pancreatic cell transplantations. As an alternative, in vitro generation of insulin-secreting cells and their subsequent transplantation into patients with T1D has been proposed. Insulinsecreting cells can be generated by differentiating Stem Cells (SCs), particularly pluripotent SCs [4] and pancreatic progenitor cells [5]. Here, adult pancreatic alpha-cells and precursors of acinar cells have been considered as suitable candidates for cell replacement therapy [4,6-9]. Despite the potential benefits of SC-derived cells, the insulin response to glucose in the differentiated beta cell is less intense compared to native beta cells.

Degeneration of insulin-producing beta cells in Langerhans islets is a hallmark of insulin-dependent T1D. Recent research showed that the loss of beta cells is at least partly caused by an on-going inflammation [10]. In this regard, Alnek, et al. [11] observed an increased abundance of growth factors, including Granulocyte Macrophage-Colony Stimulating Factor (GM-CSF) and Interleukin (IL)-7, the proinflammatory cytokine IL- $1 \beta$ (but not IL- 6 or Tumour Necrosis Factor (TNF)- $\alpha$ ), Th17 cytokines, and the regulatory cytokines IL-10 and IL27 in the blood of T1D patients. Moreover, Burke, et al. [12] reported that IL-1 $\beta$, a major mediator of inflammatory responses associated with diabetes development, is co-ordinately and reciprocally regulating chemokine and insulin secretion. In addition, IL- $1 \beta$ is known to have potent cytotoxic effects leading to progressive beta cell death [13]. In particular, inflammation negatively affects GLP-1 binding to G ProteinCoupled Receptors (GPCRs) located on pancreatic beta cells. GLP-1 is a neuropeptide and an incretin derived from the transcription product of the proglucagon gene, exerting insulinotropic actions that include the stimulation of insulin gene transcription, insulin biosynthesis, and insulin secretion. Diminished GLP-1 signalling mediated by inflammatory triggers lead to a considerable deterioration of insulindependent homeostasis of glucose.

*Corresponding author: Olga Victorovna Pershina, Laboratory of Regenerative Pharmacology, Goldberg ED Research Institute of Pharmacology and Regenerative Medicine, Tomsk National Research Medical Centre of the Russian Academy of Sciences, Tomsk, Russia, Tel: 8(3822) 3822-418-374; Fax: +7-3822-418-375 E-mail: ovpershina@gmail.com

Received July 20, 2018; Accepted August 14, 2018; Published August 20, 2018

Citation: Skurikhin EG, Pershina OV, Ermakova NN, Ermolaeva LA, Krupin VA, et al. (2018) Polytherapy with Reserpine and Glucagon-like Peptide-1 (GLP1) Improves the Symptoms in Streptozotocin-Induced Type-1 Diabetic Mice by Reducing Inflammation and Inducting Beta Cell Regeneration. Stem Cell Res Ther 8: 434. doi: 10.4172/2157-7633.1000434

Copyright: (c) 2018 Skurikhin EG, et al. This is an open-access article distributed under the terms of the Creative Commons Attribution License, which permits unrestricted use, distribution, and reproduction in any medium, provided the original author and source are credited. 
Citation: Skurikhin EG, Pershina OV, Ermakova NN, Ermolaeva LA, Krupin VA, et al. (2018) Polytherapy with Reserpine and Glucagon-like Peptide-1 (GLP-1) Improves the Symptoms in Streptozotocin-Induced Type-1 Diabetic Mice by Reducing Inflammation and Inducting Beta Cell Regeneration. Stem Cell Res Ther 8: 434. doi: 10.4172/2157-7633.1000434

Page 2 of 11

Recently, promising results in treating autoimmune diseases were obtained after transplantation of Haematopoietic Stem Cells (HSCs) [14]. Moreover, HSCs have the ability to decrease hyperglycemia [15]. Thus, application of both autologous and allogeneic HSCs has been considered a potential treatment for T1D [16-18]. However, it has been reported that adult bone marrow HSCs change their properties in an inflamed environment [19-23]. During bacterial or viral infection, adult bone marrow HSCs leave their niches [24,25] accompanied by activation and differentiation as a response to inflammatory signals [26]. In this regard, several studies showed the loss of HSCs lymphoid potential and differentiation into myeloid cells [19-23]. In addition, monitoring HSCs in animals with microbial infection revealed migration and accumulation in extramedullary tissues [27].

Several studies point out that the Sympathetic Nervous System (SNS) maintains homeostasis of various cell populations, particularly influencing HSCs fate [28-30]. SNS is necessary for formation of islet architecture during development of the pancreas [29]. In this regard, noradrenalin blocks insulin secretion by acting on $\alpha 2$ receptors of Langerhans islets beta cells in the adult organism [30-33]. Drugs affecting the SNS are considered as potential co-treatment in cell replacement therapy. For example, reserpine is known to block the VMAT in nerves of the SNS.

In this study, we induced diabetic phenotype in C57BL/6 mice using STZ and assessed the effect of sympatholytic reserpine on hyperglycemia, insulinaemia and pathological parameters of the pancreas. Moreover, we analysed the secretion of pro-inflammatory cytokines, as well as the effect of reserpine on HSCs and Haematopoietic Progenitor Cells (HPCs). In addition, we compared the effects of reserpine with a combination of reserpine and GLP-1 on pancreatic beta cells and $\mathrm{Pdx} 1^{+}$beta cell progenitors.

We show for the first time that reserpine disrupts the mobilisation of bone marrow HSCs and HPCs into the blood stream, which is accompanied by an inhibition of their migration into the pancreata of C57BL/6 mice in a STZ-induced model of diabetes. Furthermore, we demonstrate that reserpine reduces inflammation in the pancreas, has a hypoglycaemic effect and raises insulin and GLP-1 concentrations in the serum. We also report increased numbers of multipotent of beta cell progenitors (CD45-TER119-c-kit Flk-1'), oligopotent beta cell precursors (CD45-TER119-CD133+CD49f low) and $\mathrm{Pdx} 1^{+}$beta cells in the diabetic pancreata. Our results point towards a higher regenerative efficiency of pancreatic beta cells after polytherapy with reserpine and GLP-1 compared to reserpine alone. According to our findings, the use of sympatholytic reserpine to decrease inflammation, followed by the application of GLP-1, could be considered as a new strategy for beta cell regeneration in the diabetic pancreas.

\section{Materials and Methods}

\section{Setting}

Department of Experimental Biological Models, Goldberg ED Research Institute of Pharmacology and Regenerative Medicine, Tomsk National Research Medical Centre of the Russian Academy of Sciences. All experiments were performed with the approval of the Animal Care and Use Committee of the Goldberg ED Research Institute of Pharmacology and Regenerative Medicine (Protocol No. 94092015).

Experiments were performed between 8:00 and 13:00 hrs.

\section{Sample, sampling technique and animals}

Sample size was calculated using sample-size calculating software
$\mathrm{G}^{\star}$ Power version 3.1.10 (Program written, concept and design by Franz, Universitat Kiel, Germany. Freely available windows application software). With power of $80 \%, 0.05$ statistical level of significance and effect size of 1 sample size for each test was calculated to be 17 . We performed 3 independent experiments therefore rounded off that number to 18 . Therefore, for two different tests, sample size was $2 \times$ $18=36$. There were 5 groups of animals; sample size was $36 \times 5=180$.

One hundred and eighty male C57BL/6 mice were randomly assigned into one of the five experimental groups.

All mice were housed individually in cages under standard 12:12 hrs light:dark cycle. Water and food were available ad libitum until mice were transported to the laboratory, approximately 1 hour prior to the experiments. Mice were randomized into 5 equal groups. Group 1 mice (intact control) were kept under standard vivarium conditions. Mice with fasting blood glucose levels exceeded $8 \mathrm{mmol} / \mathrm{L}$ were diagnosed as diabetic mice and selected for further experiment. These mice were randomly divided into four groups: diabetic group - group 2- mice with STZ-induced diabetes and treated by $0.1 \mathrm{ml}$ of $0.9 \% \mathrm{NaCl}$; group 3- mice with STZ-induced diabetes and treated by reserpine; group 4mice with STZ-induced diabetes and treated by GLP-1; group 5- mice with STZ-induced diabetes and treated by consistently administered reserpine and GLP-1.

\section{Reagents}

STZ is a glucosamine-nitrosourea compound derived from Streptomyces achromogenes that is used clinically as a chemotherapeutic agent in the treatment of pancreatic beta cell carcinoma. STZ damages pancreatic beta cells (Sigma, USA). Reserpine irreversibly blocks the VMAT (Sigma, USA). GLP-1 is a neuropeptide and an incretin derived from the transcription product of the proglucagon gene (Sigma, USA). GLP-1 binds with high affinity to GPCRs located on pancreatic beta cells, and it exerts insulinotropic actions that include the stimulation of insulin gene transcription, insulin biosynthesis, and insulin secretion.

\section{The effect of reserpine on $\mathrm{C} 57 \mathrm{BL} / 6$ mice maintained under optimal conditions}

During the study of the reserpine effect on mice maintained under optimal conditions we used additional eighteen C57BL/6 male mice. Mice were randomized into 3 equal groups $(n=6)$. Group 1 mice (intact controls) were kept under standard vivarium conditions; groups 2 and 3 mice received sympatholytic reserpine. Reserpine was injected intraperitoneally in single dose $0.1 \mathrm{mgkg}^{-1}$ in $0.1 \mathrm{ml}$ of $0.9 \% \mathrm{NaCl}$. Control group was consisted of intact mice. Control animals were administered a single intratracheal $0.1 \mathrm{ml} 0.9 \% \mathrm{NaCl}$. We evaluated the effect of reserpine on the amount of Lin- -cells, HSCs and HPCs in bone marrow, pancreata and blood of mice in $7 \mathrm{~min}$ (group 2) and $2 \mathrm{hrs}$ (group 3) after injection.

\section{STZ-induced diabetes}

Experimental diabetes was induced in C57BL/6 mice by intraperitoneal injections of multiple low doses of STZ $\left(40 \mathrm{mgkg}^{-1}\right.$ (Sigma) daily for 5 days, diluted in $150 \mu \mathrm{l}$ Phosphate-Buffered Saline (PBS) after $4 \mathrm{hrs}$ fasting). Diabetes was confirmed by monitoring blood glucose level. The day of the last STZ injection was considered as experimental day 0 . Blood glucose was measured on experimental days $0,4,14,21,29$ and 38 using Accu-Chek ${ }^{\circledR}$ Performa Nano Meter (Roche, Germany) under non-fasting conditions. At the designated time points (days 4, 14, 21, 27 or 38 after the last dose of STZ) the mice 
Citation: Skurikhin EG, Pershina OV, Ermakova NN, Ermolaeva LA, Krupin VA, et al. (2018) Polytherapy with Reserpine and Glucagon-like Peptide-1 (GLP-1) Improves the Symptoms in Streptozotocin-Induced Type-1 Diabetic Mice by Reducing Inflammation and Inducting Beta Cell Regeneration. Stem Cell Res Ther 8: 434. doi: 10.4172/2157-7633.1000434

Page 3 of 11

were sacrificed by $\mathrm{CO}_{2}$ asphyxiation. Blood was collected and the bone marrow and pancreatic gland were isolated.

\section{Reserpine and GLP-1 administration}

Reserpine and GLP-1 were applied in both monotherapy and polytherapy in C57BL/6 mice after confirmation of STZ-induced diabetic phenotype. Reserpine was administered intraperitoneally in dose of $0.1 \mathrm{mgkg}^{-1}$ in $0.1 \mathrm{ml} \mathrm{PBS}$ for 10 days starting on day 28. GLP1 was injected intraperitoneally in dose of $2.0 \mathrm{mgkg}^{-1}$ in $0.1 \mathrm{ml} \mathrm{PBS}$ for 5 days starting on day 33. For combination treatment, GLP-1 was injected intraperitoneally 1 hour after reserpine injection on day 33 for the following 5 days of the experiment. The mice were sacrificed by $\mathrm{CO}_{2}$ overdose on day 38 of the experiment. Simultaneously, blood was collected, and the bone marrow and pancreas were isolated. Langerhans islets were examined morphologically. Levels of IL- $1 \beta$, insulin and GLP1 in serum were evaluated, HSC and HPC in the blood, bone marrow and pancreas, multipotent beta cell progenitor, oligopotent beta cell precursors and $\mathrm{Pdx} 1^{+}$beta cells in the pancreas.

\section{Histology}

For histologic analysis, pancreas were isolated, collected and immediately fixed in $10 \%$ formalin. Specimens were processed, embedded in paraffin and cut into sections. Hematoxylin-Eosin (H\&E) was performed to assess pancreas architecture and inflammatory cells (neutrophils, lymphocytes, and macrophages). Langerhans islets were examined morphologically by measuring the islet area, total islet cells and the amount of pyknotic and inflammatory cells. At least 10 photomicrographs of the pancreas tissue at 100x magnification were taken for each experimental animal. Imaging was performed using a Axio Lab.A1 microscope (Carl Zeiss $\mathrm{GmbH}$, Göttingen, Germany) with a AxioCam ERc5s (Carl Zeiss, Göttingen, Germany). Images were processed using AxioVision Rel.4.8.2 software.

\section{Immunohistochemistry}

The $4 \mu \mathrm{m}$ thick sections were placed onto slides coated with poly1-lysine (PLL, Sigma-Aldrich, USA) then deparaffinized in xylene and rehydrated in graded alcohol. For immunohistochemical analysis, insulin in the pancreas islets was detected using a rabit polyclonal anti-insulin antibody (1:900, ab63820, Abcam, USA) and Anti-Rabbit HRP DAB Detection System (Spring bioscience, USA) following the manufacturer's protocol. After staining slides were dehydrated in xylene and were placed on coverslips. The specificity of insulin immunoreactivity was confirmed by omitting the primary antibodies from some sections. Sections were counterstained with hematoxylin. Images were collected on a Axio Lab.A1 microscope (Carl Zeiss GmbH, Göttingen, Germany) with a AxioCam ERc5s (Carl Zeiss, Göttingen, Germany) and analyzed with Fiji is Just ImageJ extended software, by determining the average pixel value of staining per islet. Background staining was subtracted from each value.

\section{Enzyme linked immunosorbent assay}

The concentrations of IL- $1 \beta$, insulin and GLP-1 in serum were determined by ELISA according to manufacturer's instructions (Cusabio Biotech CO., Ltd, China). Sensitivities were $>7.8 \mathrm{pg} / \mathrm{ml}$ for IL- $1 \beta,>3.9 \mathrm{nIU} / \mathrm{ml}$ for insulin, $>0.078 \mathrm{pg} / \mathrm{ml}$ for GLP-1.

\section{Flow cytometric analysis}

Membrane receptor's expression of murine HSCs from bone marrow, blood and pancreas were assayed according to manufacturer's guidelines using BD Mouse Hematopoietic Stem and Progenitor
Cell Isolation Kit (BD Biosciences, US). Surface Mouse Fc receptors were blocked by incubating the cell pellet with $5 \mu \mathrm{L}$ of purified rat anti-mouse CD16/CD32 (Mouse BD Fc Block ${ }^{\mathrm{TM}}$ ) for 5 min on ice. The mononuclear cells were then co-stained with the recommended amounts of surface markers CD34 (FITS), c-kit (PE), Sca-1 (PE-Cy 7), and Lineage Cocktail (APC Mouse Lineage Antibody Cocktail (CD3, CD45R (B220), Ly6C and Ly6G (Gr1), CD11b (Mac1), TER-119) (BD PharmingenTM)) for $30 \mathrm{~min}$. Labelled cells were thoroughly washed with PBS and analysed on FACSCanto II (Becton Dickinson) with the FACS Diva software. A minimum of 100,000 events were recorded for each condition.

Membrane receptor expression of cells from pancreata was analysed using BD surface markers (BD Biosciences, USA). Mononuclear cells were stained for $30 \mathrm{~min}$ using the following antibodies: anti-mouse CD45 (PerCP), TER119 (APC-Cy7), CD117 (c-kit) (PeCy7), CD49f (FITC), CD309 (Flk-1/(APC) and PDX1 (PE) (BD Biosciences, USA) and CD133 (PE) (BioLegend). FITS Rat IgG2a, PerCP Mouse IgG1, APC Rat IgG2b, APC-Cy7 Rat IgG2b, PE Rat IgG2a (BioLegend) were used as isotype controls. Intracellular staining of PDX1 was performed according to the manufacturer's instruction. FACS analysis was performed as described above [34].

\section{Statistical analysis}

Statistical analysis was performed using SPSS statistical software (version 15.0, SPSS Inc., Chicago, IL, USA). Data was analysed and presented as means \pm standard error of mean. A two-sided unpaired Student t-test (for parametric data) or Mann-Whitney test (for nonparametric data) was used according to distribution. A P value of less than 0.05 (by two-tailed testing) was considered an indicator of statistical significance.

\section{Results}

\section{STZ administration leads to development of diabetic phenotype in $\mathrm{C} 57 \mathrm{BI} / 6$ mice}

In order to compare histological changes of pancreata of STZinduced diabetic mice and healthy controls, pancreata were isolated followed by sectioning and histological analysis. A normal histological structure was observed in healthy mice. The islets of Langerhans appeared as non-capsulated, pale stained, round or oval areas inside the pancreatic lobules, formed by groups of cells arranged in irregular, ranching, and anastomosing cords separated by blood capillaries (Figure 1A). In contrast, in pancreata of diabetic mice, oedema and hyperaemia were observed (Figure 1). This was accompanied by infiltration of neutrophils, macrophages, and lymphocytes on days 14-38 following the last STZ injection (Figure 1B). Starting from day 14, diabetic mice demonstrated persistent degeneration of insular tissue area when compared to control animals (Figures $1 \mathrm{~B}$ and $\mathrm{S} 1$ ). In the control group, the total islet cellularity was $70 \%,<50 \%$, and $69.72 \%$ on days 21,27 , and 38 , respectively. In contrast, STZ increased the percentage of pyknotic cells two fold (21 days), 2.3 times (day 27) and 3.81 times (day 38) (Figure S1). In addition, fibroblasts were detected in the Langerhans islets of diabetic mice after day 27, suggesting development of insular sclerosis. Finally, administration of STZ resulted in significantly increased blood glucose levels (Figure 2A). In sum, administration of STZ caused a diabetic phenotype including morphological changes along with increased blood glucose levels. 
Citation: Skurikhin EG, Pershina OV, Ermakova NN, Ermolaeva LA, Krupin VA, et al. (2018) Polytherapy with Reserpine and Glucagon-like Peptide-1 (GLP-1) Improves the Symptoms in Streptozotocin-Induced Type-1 Diabetic Mice by Reducing Inflammation and Inducting Beta Cell Regeneration. Stem Cell Res Ther 8: 434. doi: 10.4172/2157-7633.1000434

Page 4 of 11
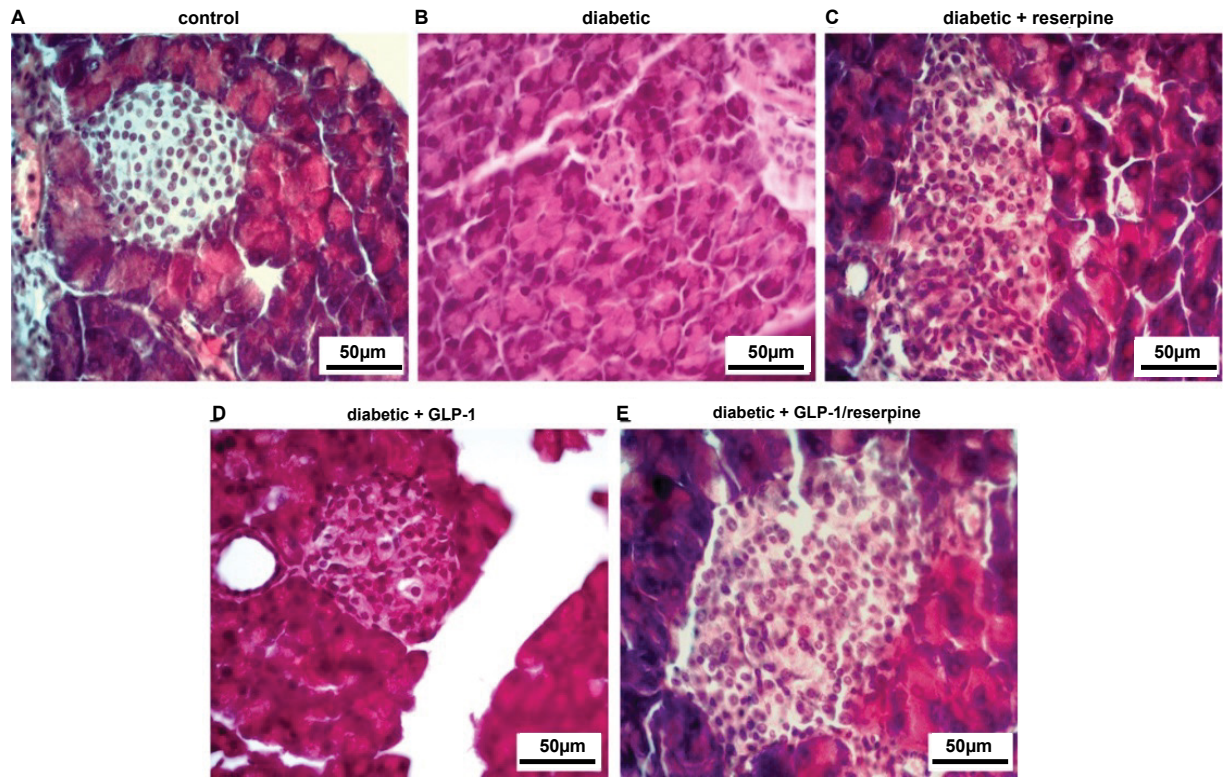

Figure 1: Polytherapy with GLP-1 and reserpine improves histological features in STZ-induced diabetic phenotype in C57BI/6 mice. Photomicrographs of representative pancreas sections obtained from C57BL/6 mice after STZ administration (38th day of the experiment). Tissue was stained with haematoxylin-eosin. A) Section from control group pancreas $(0.9 \% \mathrm{NaCl})$ shows granulated cytoplasm of islet cells with small, dark nuclei on the periphery (alpha-cells) or with light and large nuclei (beta cells). B) Section from pancreas of a diabetic mouse reveals degenerative cytoplasmic changes in most islet cells, especially in center of the islet. Note the irregular outlining of the islet. C) Section from diabetic mice treated with reserpine $\left(0.1 \mathrm{mgkg}^{-1}\right)$. D) Section from pancreas of diabetic mice treated GLP-1 (2.0 mgkg-1). E) Pancreas of mice with diabetes after reserpine and GLP-1 administration shows the nearly regular outline of an islet with normal appearance of most cells. Bar: $50 \mu \mathrm{m}$.

\section{Reserpine reduces the blood glucose levels and improves cellularity of the pancreata in diabetic mice}

Next, we studied the effects of reserpine or/and GLP-1 administration on the inflammation, cellularity and blood glucose levels of diabetic mice (Figures 1 and 2). Here, we were able to detect significantly reduced blood glucose levels after treatment of diabetic mice with reserpine and a combination of GLP-1 and reserpine (Figure 2A). Moreover, reserpine significantly reduced the edema in diabetic mice (Figure 1C) and increased the total islet cellularity (to 2.48 times) and the area of the islet tissue in the pancreas of the diabetic animals compared to controls (Figure S1). At the same time, the percentage of pyknotic cells in the Langerhans islets from pancreas of reserpinetreated diabetic mice was reduced (by $74 \%$ in comparison with untreated diabetic mice) to the level of control group mice (Figure S1). In addition, no fibroblasts were identified after reserpine exposure in STZ-affected islets. However, GLP-1 had no effect on the morphology of pancreata isolated from mice with diabetes (Figure 1D). The changes in the pancreata after combination treatment using reserpine and GLP1 were similar to reserpine monotherapy (Figure 1E).

Taken together, reserpine reduced blood glucose levels in diabetic mice and improved histopathological parameters of pancreata, independent on administration as monotherapy or polytherapy (reserpine together with GLP-1).

\section{Immunohistochemistry}

In addition measurements, we analyzed insulin content in situ using insulin immune reactivity per islet. In the islets from control animals, there was strong insulin staining in all beta cells (Figure 3A). However, in diabetic groups, there was weak insulin immunoreactivity and it was found in only a few beta cells within the islets (Figure 3B). Interestingly, in the exercised diabetic group, there was an increase in the insulin labeling intensity (Figure 3F).
Polytherapy with reserpine and GLP-1 leads to reduced amounts of IL-1 $\beta$ and increases levels of serum insulin and GLP-1

The identified beneficial effects of reserpine on blood glucose levels and restoration of pancreas architectonics in diabetic mice prompted us to evaluate the effect of the treatments on the levels of the proinflammatory IL- $1 \beta$, insulin and GLP-1. In particular, using ELISA, we evaluated IL-1 $\beta$, insulin and GLP-1 levels in the serum 38 days after STZ administration (Figure 2 (B-D)). Injections of STZ led to increased levels of serum IL-1 $\beta$ (up to $158.3 \%$ ) and decreased insulin levels (up to $67.7 \%$ ) compared to control mice, while GLP-1 levels did not change.

Reserpine reduced IL-1 $\beta$ levels (to $47 \%$ ) and increased insulin (up to $363 \%$ ) and GLP-1 (up to 550\%) levels in serum of STZ-induced diabetic mice (Figure 2 (B-D)). Similarly, GLP-1 treatment increased serum GLP-1 levels (up to 587\%). However, GLP-1 administration had no effect on the levels of serum insulin. Importantly, polytherapy using reserpine and GLP-1 resulted in stronger increase of insulin (up to 567\%) and GLP-1 levels (upto 952\%) than the monotherapy.

In sum, reserpine reduced IL- $1 \beta$ secretion and increased insulin and GLP-1 serum levels in diabetic mice. Polytherapy with reserpine and GLP-1 increased the levels of insulin and GLP-1 in serum more effectively than monotherapy with reserpine alone.

Administration of reserpine leads to a short term increase of the numbers of HSC and HPC in bone marrow but reduces their count in the blood and pancreata of non-diabetic C57BL/6 mice

Previously, we reported that reserpine increases the number of LT-HSCs (Lin-Sca- $1^{+}$c-kit ${ }^{+}$CD34), ST-HSCs (Lin-Sca- $1^{+}$c-kit ${ }^{+}$CD34 ${ }^{+}$) and HPCs $\left(\mathrm{Lin}-\mathrm{Sca}-1^{+} \mathrm{c}-\mathrm{kit}^{+}\right)$in the bone marrow and blood of healthy 
Citation: Skurikhin EG, Pershina OV, Ermakova NN, Ermolaeva LA, Krupin VA, et al. (2018) Polytherapy with Reserpine and Glucagon-like Peptide-1 (GLP-1) Improves the Symptoms in Streptozotocin-Induced Type-1 Diabetic Mice by Reducing Inflammation and Inducting Beta Cell Regeneration. Stem Cell Res Ther 8: 434. doi: 10.4172/2157-7633.1000434

A

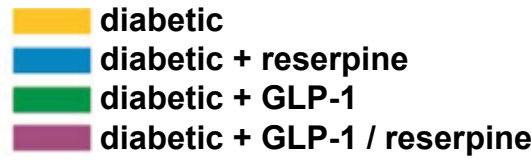

*

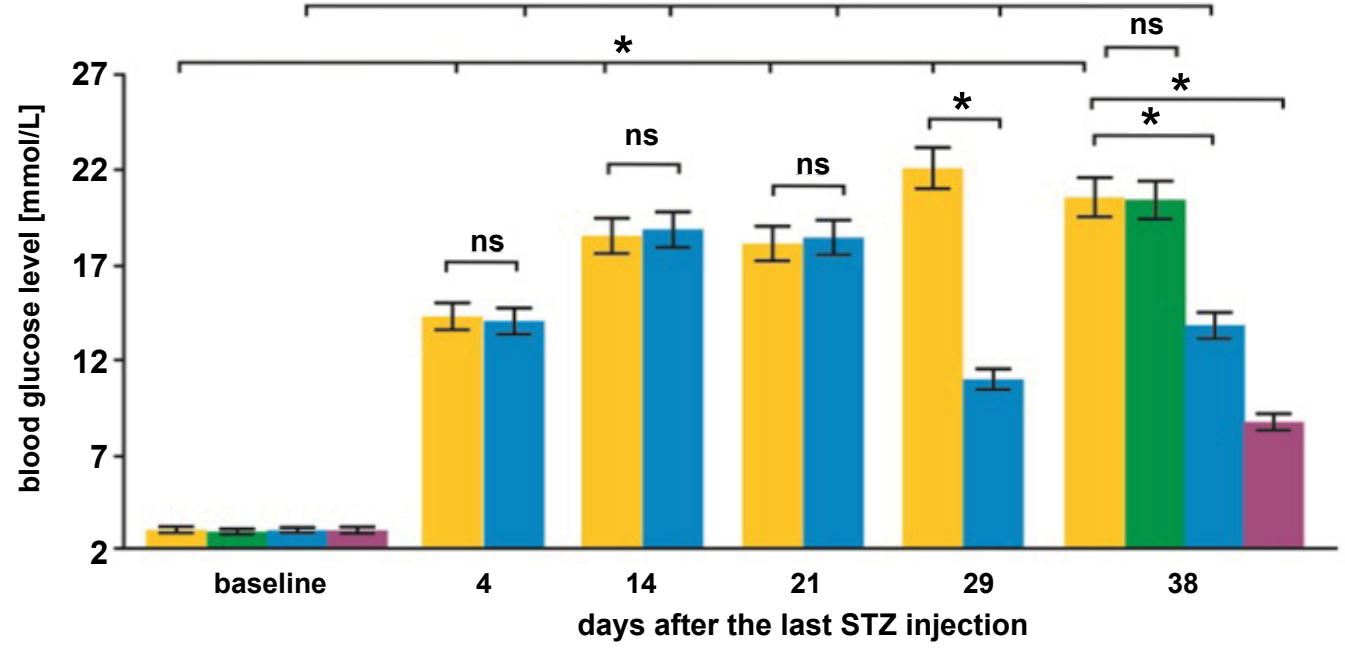

B
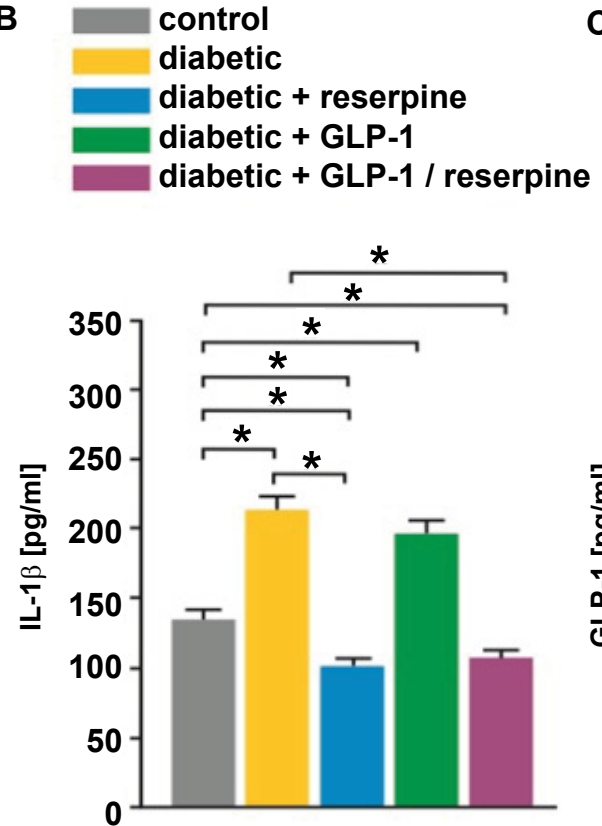

C

D
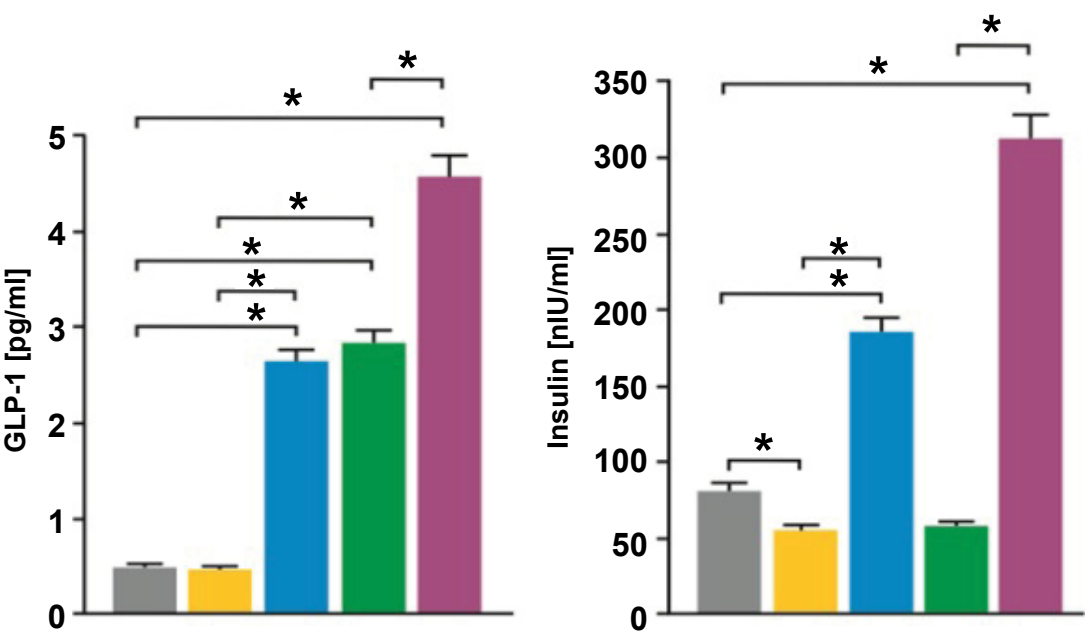

Figure 2: Reserpine reduces blood glucose and serum IL-1 $\beta$ levels, while increasing serum insulin and GLP-1 levels in diabetic mice. A) Blood glucose was measured using Accu-Chek ${ }^{\circ}$ Performa Nano Meter (Roche, Germany). Both, administration of combination of GLP-1 and reserpine and reserpine alone results in a significant decrease of blood glucose level in diabetic mice. Data represent mean of 3 independent experiments, $n=6 /$ group. Results are presented as the mean \pm SEM. ${ }^{*} P<0.05$ were considered significant, unpaired Student's t-test. Baseline mean before STZ inject in each group. B) STZ-administration significantly elevates serum level of the pro-inflammatory cytokine IL- $1 \beta$ compared to control mice treated with $0.9 \% \mathrm{NaCl}$. Treatment with reserpine and reserpine/GLP-1 leads to significantly reduced serum $\mathrm{IL}-1 \beta$, whereas no reduction is observed in animals treated with GLP-1 alone. Data represent mean and SEM of 3 independent experiments, $\mathrm{n}=6 /$ group. ${ }^{*} \mathrm{P}<0.05$ were considered significant. C) Administration of GLP-1, reserpine and polytherapy with GLP-1 and reserpine increases GLP-1 levels in diabetic mice. Note that GLP-1 levels in mice after GLP-1/reserpine polytherapy are significantly higher compared to both diabetic mice and diabetic mice after GLP-1 and reserpine monotherapy. D) Polytherapy with reserpine and GLP-1 increases serum insulin levels in STZ-induced diabetes. Note that both, monotherapy with reserpine and polytherapy with GLP-1/reserpine elevated serum levels of insulin compared to diabetic and healthy control mice.

mice 7 min and 2 hrs post administration (Figure 4) [35]. In the present study we evaluated the effect of reserpine administration on LT-HSCs, ST-HSCs and HPCs count in pancreata (Figure 4 (A-C,E,F)). In accordance with our previous report [35], reserpine increased the numbers of LT-HSCs, ST-HSCs and HPCs in blood and bone marrow. Moreover, reserpine reduced the number of ST-HSC and HPCs in pancreata of healthy mice compared to the control after 7 min (Figure $4(\mathrm{E}, \mathrm{F})$ ), whereas Lin - cell count was increased to $133 \%$ of the control 
Citation: Skurikhin EG, Pershina OV, Ermakova NN, Ermolaeva LA, Krupin VA, et al. (2018) Polytherapy with Reserpine and Glucagon-like Peptide-1 (GLP-1) Improves the Symptoms in Streptozotocin-Induced Type-1 Diabetic Mice by Reducing Inflammation and Inducting Beta Cell Regeneration. Stem Cell Res Ther 8: 434. doi: 10.4172/2157-7633.1000434

Page 6 of 11

(Figure 4D). 2 hrs post reserpine injection HSCs and HPCs were absent in the pancreata (Figure $4(\mathrm{E}, \mathrm{F})$ ). Furthermore, $7 \mathrm{~min}$ and $2 \mathrm{hrs}$ after reserpine injection HSCs and HPCs could not be detected in the blood (Figure 4 (E,F)). Simultaneously, the amount of Lin -cells increased to $163 \%$ and $148 \%$ respectively when compared to the control group (Figure 4D).

\section{Reserpine decreases mobilisation of LT-HSCs, ST-HSCs and HPCs into the blood steam and pancreata}

Recently, we demonstrated that STZ-induced diabetes results in reduced HPCs, ST-HSCs and LT-HSC count in bone marrow, blood and pancreata of mice [36]. In accordance with these findings, significantly decreased numbers of LT-HSCs $(0.049 \pm 0.004 \%$ vs $0.0197 \pm 0.002 \%)$, ST-HSC $(0.597 \pm 0.055 \%$ vs $0.347 \pm 0.033 \%)$ and HPC $(0.664 \pm 0.062 \%$ vs $0.383 \pm 0.034 \%)$ were observed in bone marrow of diabetic mice compared to the control group (Figure 4 (A-C, H-J)). ST-HSCs were absent in blood and pancreata of mice with diabetes, while LT-HSCs and HPCs were higher compared to the control (Figure 4 (A,B,H-I)). Next, we investigated the impact of reserpine administration on abundance of LT-HSCs, ST-HSCs and HPCs in diabetic mice. Here, reserpine treatment led to higher numbers of LT-HSCs $(0.0197 \pm 0.002 \%$ vs 0.027 $\pm 0.0023 \%)$, ST-HSCs $(0.347 \pm 0.033 \%$ vs $0.539 \pm 0.05 \%)$ and HPCs $(0.383 \pm 0.034 \%$ vs $0.589 \pm 0.054 \%)$ in the bone marrow of diabetic mice compared to untreated diabetic animals (Figure 4 (A-C,H-J)). In addition, no LT-HSCs could be detected in the blood of the reserpine group (Figure 4J). Moreover, the numbers of ST-HSCs (by 72.8\%) and HPCs (by $64.8 \%$ ) were decreased compared to the diabetic control (Figure $4(\mathrm{H}, \mathrm{I})$ ) while no LT-HSCs and HPCs have been found in pancreas of the reserpine group (Figure $4(\mathrm{C}, \mathrm{H}-\mathrm{J})$ ).

In sum, reserpine administration resulted in in a diminished mobilisation of bone marrow HSCs and HPCs into the blood stream along with a reduced migration into the pancreata of diabetic mice.

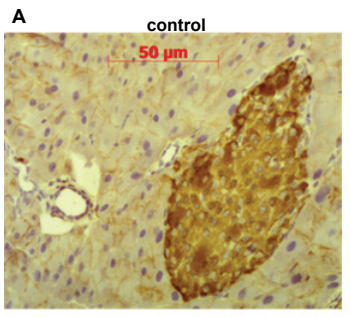

D
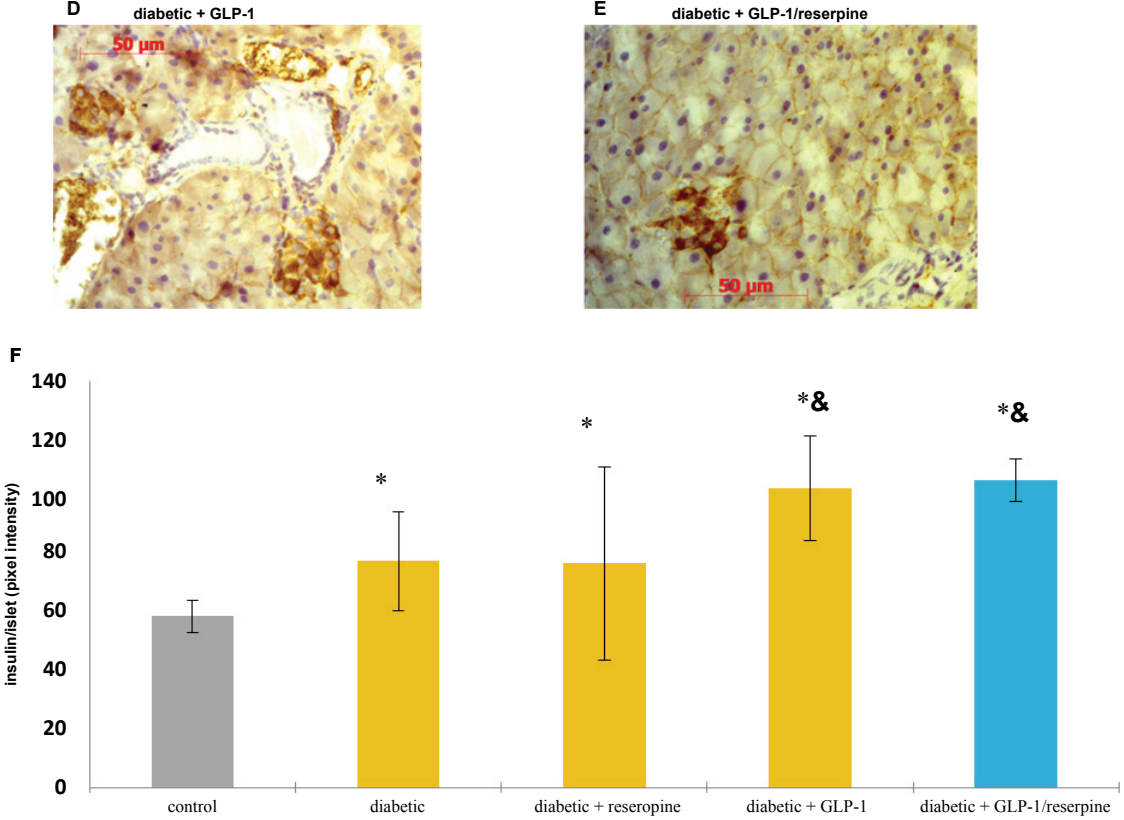

Figure 3: Photomicrographs of insulin immunohistochemical staining of pancreatic islets and insulin content per islet in STZ-induced diabetic phenotype in C57BL/6 mice. Photomicrographs of representative pancreas sections obtained from C57BL/6 mice after STZ administration (38th day of the experiment). Immunohistochemical stain showing the intensity of insulin-immunoreactive cells in islets from pancreatic sections. A) Section of the pancreas of the control group ( $0.9 \%$ NaCl) shows typical islet dark insulin staining (brown) throughout the islet. B) Section of pancreas of the diabetic mouse reveals degenerative cytoplasmic changes in most islet

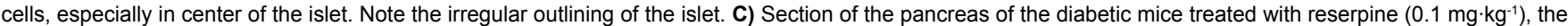
apparent decrease in number and area of beta-cells is evident in comparison with control group (A). D) Section of pancreas of the diabetic mice treated GLP-1 (2.0 $\mathrm{mg} \cdot \mathrm{kg}^{-1}$ ), presenting an apparent increase in the number and area of beta-cells compared with group 3B. E) Section of pancreas of the mice with diabetes treated with reserpine and GLP-1 showing an evident increase in insulin expressing beta-cells with normal density, compared with diabetic group 3B. (Scale bar: 50 um.) F) Quantification of the intensity of insulin-positive staining per islet in pancreatic sections (intensity of staining DAB without color separation). Therapy with reserpine and GLP1 improved the total insulin staining intensity per islet significantly. *-compared to the mice received $0.9 \% \mathrm{NaCl}(\mathrm{control})(\mathrm{P}<0.05)$, \& - compared to the mice received $\mathrm{STZ}$ and $0.9 \% \mathrm{NaCl}$ treated (diabetic) $(\mathrm{P}<0.05)$, $\mathrm{t}$ test was used. 
Citation: Skurikhin EG, Pershina OV, Ermakova NN, Ermolaeva LA, Krupin VA, et al. (2018) Polytherapy with Reserpine and Glucagon-like Peptide-1 (GLP-1) Improves the Symptoms in Streptozotocin-Induced Type-1 Diabetic Mice by Reducing Inflammation and Inducting Beta Cell Regeneration. Stem Cell Res Ther 8: 434. doi: 10.4172/2157-7633.1000434
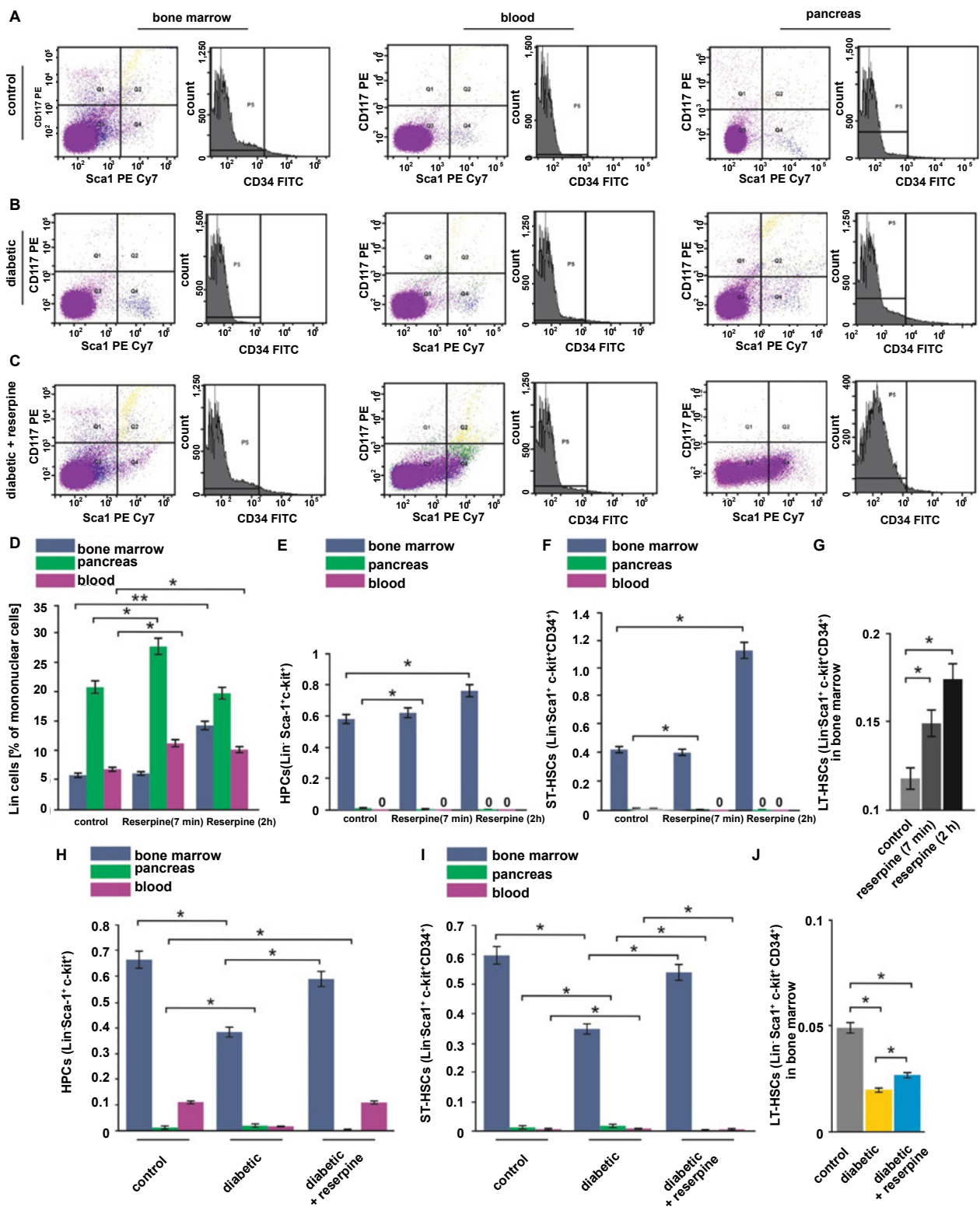

G
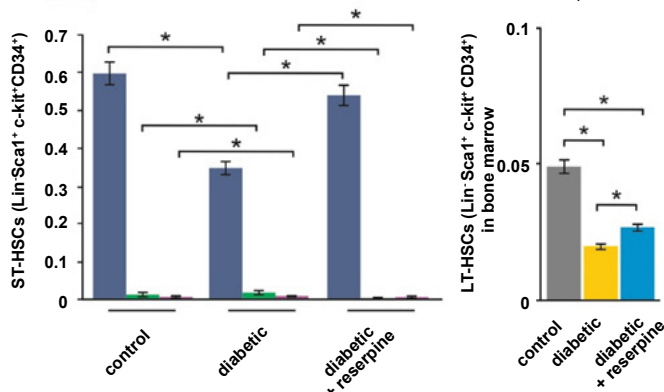

Figure 4: Administration of reserpine leads to a short term increase of the numbers of HSC and HPC in blood marrow but reduces their count in the blood and pancreata of non-diabetic C57BL/6 mice, while decreasing mobilization of LT-HSCs, ST-HSCs, and HPCs into the blood steam and pancreata in diabetic mice. A-C) Characterization of hematopoietic stem cells (HSC) and hematopoietic progenitor cells (HPC) isolated from bone marrow, blood and pancreas of C57BL/6 mice with and without STZ-induced diabetes and diabetic mice treated with reserpine. Membrane receptor's expression of murine HSCs derived from bone marrow, pancreas and blood were assayed according to the protocol for BD Mouse Hematopoietic Stem and Progenitor Cell Isolation Kit (BD Biosciences, USA). The HSC population was separated using Lin selection (not shown) followed by Sca1 $1^{+}$and c-kit ${ }^{+}$, and gated for CD34- (P5) and CD34 ${ }^{+}$(not P5). Lin-Sca1 ${ }^{+} \mathrm{c}-\mathrm{kit}^{+} \mathrm{CD} 34^{-}$cells were considered as LT-HSCs, Lin Sca $1^{+} \mathrm{c}-\mathrm{kit}^{+} \mathrm{CD} 34^{+}$cells are considered ST-HSCs. Thus, all two of these populations can be readily sorted from one sample. Dot plots are representative for three independent experiments with the mean from three independent experiments. Results are presented as mean and SEM. D-F) The effect of reserpine treatment on count of Lin- -cells, HPCs and ST-HSCs in bone marrow, pancreata and blood of healthy C57BL/6 mice (percentage of the labelled non-adherent mononuclear cells). G) The effect of reserpine treatment on count of LT-HSCs in bone marrow of healthy C57BL/6 mice (percentage of the labelled non-adherent mononuclear cells). The content of HSCs and HPCs in the bone marrow, pancreas and blood of C57BL/6 mice without diabetes was assessed using flow cytometry 7 min and $2 \mathrm{~h}$ after reserpine administration in single dose $0.1 \mathrm{mg} \cdot \mathrm{kg}^{-1}$ in $0.1 \mathrm{ml}$ of $0.9 \% \mathrm{NaCl}$. ${ }^{*} \mathrm{P}<0.05$ and ${ }^{* *} \mathrm{P}<0.01$ were considered significant. ST-HSCs were absent in blood and pancreas of mice. H-I) Effect of reserpine treatment on the HPCs, ST-HSCs and LT-HSCs count in bone marrow, blood and pancreas of C57BL/6 mice with diabetes on the $38^{\text {th }}$ day after last STZ administration (percentage of the labelled non-adherent mononuclear cells). J) The effect of reserpine treatment on count of LT-HSCs in bone marrow of C57BL/6 mice with diabetes on the $38^{\text {th }}$ day after last STZ administration (percentage of the labelled non-adherent mononuclear cells). ${ }^{*} \mathrm{P}<0.05$ were considered significant.

\section{Polytherapy with reserpine and GLP-1 restores pancreatic Pdx1 $^{+}$beta cell population}

Next, using flow cytometry, we assessed the numbers of multipotent beta cell progenitors (CD45-TER119-c-kit'Flk-1'), oligopotent beta cell precursors (CD45-TER119-CD133+CD49f $\left.{ }^{-1}\right)$ and $\mathrm{Pdx} 1^{+}$beta cells in diabetic mice after 38 days post STZ injection (Figure 5 (A-C)).

The amount of multipotent beta cell progenitors $(27.1 \pm 2.3 \%$ vs $20.4 \pm 1.8 \%)$ in the pancreata of diabetic mice were lower compared to 
Citation: Skurikhin EG, Pershina OV, Ermakova NN, Ermolaeva LA, Krupin VA, et al. (2018) Polytherapy with Reserpine and Glucagon-like Peptide-1 (GLP-1) Improves the Symptoms in Streptozotocin-Induced Type-1 Diabetic Mice by Reducing Inflammation and Inducting Beta Cell Regeneration. Stem Cell Res Ther 8: 434. doi: 10.4172/2157-7633.1000434

A
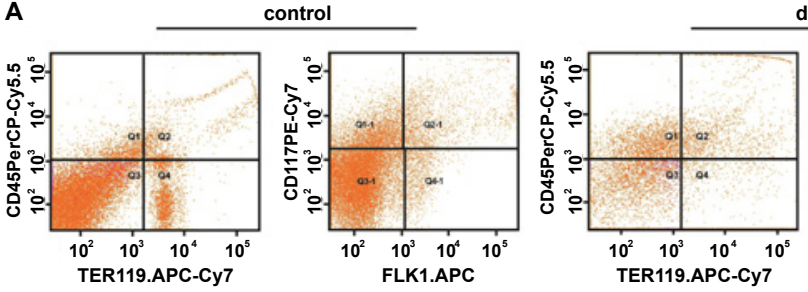

diabetic

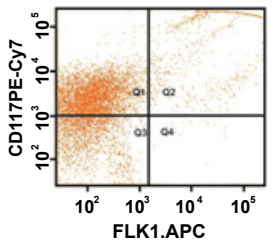

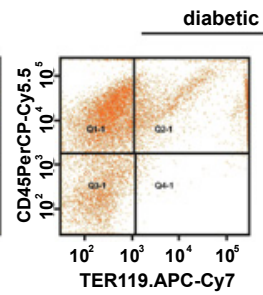

diabetic + reserpine

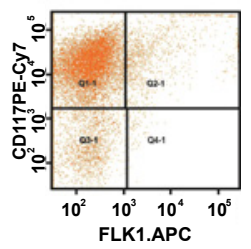

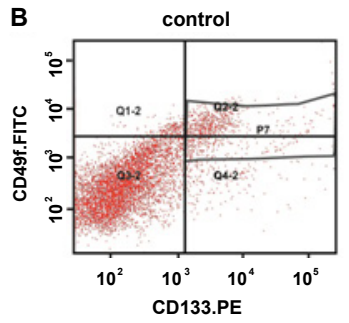
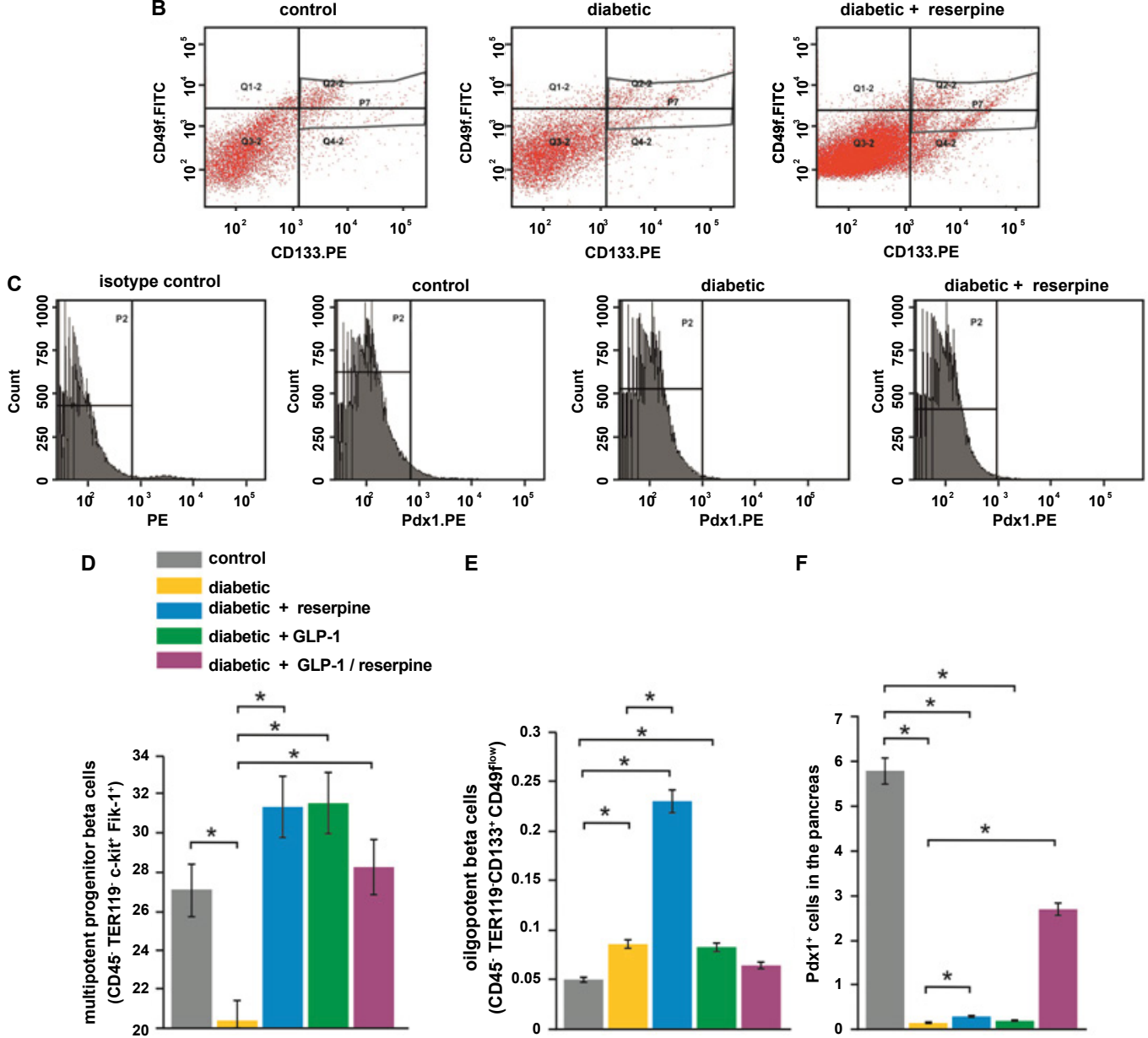

E

$\mathbf{F}$
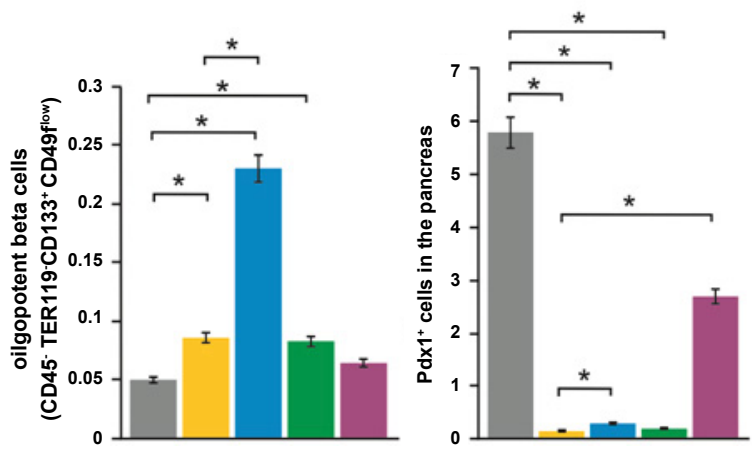

Figure 5: Characterization of multipotent beta cell progenitors (CD45-TER119 c-kit-Flk-1'), oligopotent beta cell precursors (CD45-TER119-CD133+CD49flow) and $\mathrm{Pdx} 1^{+}$beta cells isolated from pancreata of diabetic and non-diabetic C57BL/6 mice on 38th days after the last STZ administration. Cells were analysed by flow cytometry using antibodies for mouse CD45, TER119, CD133, CD49f, c-kit, Flk-1 and Pdx1. The population of CD45 and TER119 negative cells was defined as c-kit and Flk-1 negative and positive for CD133 and CD49f at the same time in the two specimens (specimen 1- subpopulation of cells with phenotype CD45-TER119-c-kit-Flk-1 and specimen 2- subpopulation of cells with phenotype CD45-TER119-CD133+CD49flow). The Pdx1 positive cells population was sorted from third specimen. Dot plots are representative for three independent experiments with the mean from three independent experiments. A) Multipotent beta cell progenitors with phenotype CD45 TER 119 c-kitFlk-1 isolated from pancreas of intact mice, control diabetic mice $(0.9 \% \mathrm{NaCl})$ and diabetic mice received reserpine. B) Oligopotent beta cell precursors with the phenotype CD45-TER119-CD133+CD49flow isolated from pancreata of intact mice, mice with diabetes, and mice with diabetes received reserpine. C) Histograms of PE Mouse IgG1 Isotype Control and expression of Pdx1 $1^{+} \mathrm{PE}$ on beta cells isolated from pancreas of intact mice, diabetic mice and mice with diabetes received reserpine. D) The content of multipotent beta cell progenitors in the pancreas of intact mice, control diabetic mice $(0.9 \% \mathrm{NaCl})$ and diabetic mice received reserpine (for diabetic mice 38th days after the last STZ administration). STZ administration leads to significantly decreased numbers of multipotent beta cell progenitors compared to $0.9 \% \mathrm{NaCl}$ treated mice. Reserpine, GLP-1 and polytherapy with GLP-1/reserpine restore the pool of multipotent progenitors. E) The content of oligopotent beta cell progenitors in the pancreas of intact mice, control diabetic mice (0.9\% NaCl) and diabetic mice received reserpine. STZ administration increases the numbers of oligopotent beta cell progenitors. Monotherapy with GLP-1 or reserpine further increased the percentage of CD45 TER 119 $\mathrm{CD} 133^{+} \mathrm{CD} 49$ flow (as compared to both diabetic and saline control). There is no significant difference to the saline control in mice receiving polytherapy with GLP-1 and reserpine. F) The content of $\mathrm{Pdx} 1^{+}$beta cells in the pancreas of intact mice, control diabetic mice (0.9\% $\mathrm{NaCl}$ ) and diabetic mice received reserpine. STZ-induced diabetes decreases the numbers of pancreatic $\mathrm{Pdx} 1^{+}$beta cells. Administration of reserpine led to a higher Pdx $1^{+}$beta cell count in diabetic mice as compared to untreated diabetic mice. Polytherapy with GLP-1 and reserpine resulted in significantly higher numbers of pancreatic Pdx $1^{+}$ beta cells compared to untreated diabetic mice. Results are presented as mean \pm SEM. ${ }^{*}$ - $<<0.05$ were considered statistically significant. 
Citation: Skurikhin EG, Pershina OV, Ermakova NN, Ermolaeva LA, Krupin VA, et al. (2018) Polytherapy with Reserpine and Glucagon-like Peptide-1 (GLP-1) Improves the Symptoms in Streptozotocin-Induced Type-1 Diabetic Mice by Reducing Inflammation and Inducting Beta Cell Regeneration. Stem Cell Res Ther 8: 434. doi: 10.4172/2157-7633.1000434

Page 9 of 11

control mice (Figure $5(\mathrm{~A}, \mathrm{D}))$. Notably, monotherapy by reserpine or GLP-1 and polytherapy using both reserpine and GLP-1 increased the number of multipotent beta cell progenitors in the pancreata of diabetic mice (Figure $5(\mathrm{~A}, \mathrm{D})$ ).

STZ administration increased the numbers of oligopotent beta cell precursors (Figure $5(\mathrm{~B}, \mathrm{E})$ ). Interestingly, monotherapy with GLP1 or reserpine further increased the percentage of CD45 TER119 $\mathrm{CD} 133^{+} \mathrm{CD} 49 \mathrm{f}^{\text {low }}$ (as compared to both diabetic and saline control), whereas no significant difference to the saline control was observed in mice receiving polytherapy with GLP-1 and reserpine (Figure $5(\mathrm{~B}, \mathrm{E})$ ).

Finally, STZ-treatment significantly decreased the numbers of pancreatic $\mathrm{Pdxl}^{+}$beta cells. Administration of reserpine alone led to a higher $\mathrm{Pdx}^{+}$beta cell count in diabetic mice in comparison with untreated diabetic mice (Figure $5(\mathrm{C}, \mathrm{F})$ ). However, the count of $\mathrm{Pdx}^{+}$ beta cells in diabetic mice after reserpine treatment was significantly lower than in control mice. Polytherapy with GLP-1 and reserpine led to significantly higher numbers of pancreatic $\mathrm{Pdx}^{+}$beta cells compared to untreated diabetic mice (Figure 5F). Taken together, polytherapy with reserpine and GLP- 1 is more effective in restoring $\mathrm{Pdxl}^{+}$beta cell population compared to monotherapy with either reserpine or GLP-1 alone.

\section{Discussion}

Reserpine, which is an antihypertensive drug, acts as an inhibitor of catecholamines and serotonin. Generally, its action on the SNS can be divided into two phases. The concentration of free monoamines increases after 3-5 min (depriming phase). During the second phase, a progressive reduction of monoamines can be observed. Notably, monoamine deficiency lasts for 2-4 hrs.

In the present work, we determined the impact of reserpine on the pathophysiology in the STZ -induced diabetes model. Here, reserpine administration resulted in significantly reduced blood glucose levels compared to untreated diabetic mice. This effect is accompanied by a 3.36 fold increase of insulin levels in sera of mice. Moreover, reserpine treatment increased the total cellularity of Langerhans islets in diabetic animals and reduced the numbers of pyknotic cells in the islets. In contrast to untreated diabetic animals, no fibroblasts have been detected in the pancreata of mice treated with reserpine. Simultaneously, reserpine reduced the secretion of IL- $1 \beta$. Furthermore, the intensity of oedema and infiltration of islet tissue of the pancreas by inflammatory cells (neutrophils, lymphocytes) (Figures 1 and S1) was diminished.

Several studies suggested that the SNS is involved in development and progression of inflammation, inhibits beta cell differentiation, and diminishes insulin secretion [30-33,37]. Thus, we evaluated if the antidiabetic and anti-inflammatory effects of reserpine could be a result of reserpine-induced inhibition of the SNS.

Initially, we did not expect that reserpine administration led to HSCs and HPCs being absent in the pancreata of diabetic mice, and that the number of circulating in blood ST-HSCs and HPCs was reduced to the intact control values. In our study, reserpine increased the number of LT-HSCs, ST-HSCs and HPCs in the bone marrow of diabetic mice while reducing their numbers in the blood stream and pancreata of diabetic animals. This suggests that HSCs and HPCs might be involved in development and progression of STZ-induced insulitis. Notably, inflammatory signals are known to influence the differentiation of bone marrow HSCs into a pro-inflammatory phenotype, their mobilisation into the bloodstream and migration into the STZ injured pancreas. It is likely that after migration to the pancreas, HSCs and progenitor cells contribute to the progression of inflammation through secretion of proinflammatory factors.

Within the bone marrow, HSCs are localised near the endosteum which is a heterogeneous layer of osteoblasts, osteogenic progenitor cells (bone-lining cells) and osteoclasts lining the medullary cavity. Notably, osteoblasts are considered as the main cellular component of endosteal lining responsible for the HSCs regulation [38-40]. Longterm repopulating and non-proliferating/quiescent HSCs are localised closer to osteoblasts and endosteum than the more mature multipotent or committed hematopoietic progenitors [41]. It has been reported that sympathetic nerve endings are present in the endosteal niche [25]. Furthermore, Elefteriou, et al. demonstrated that osteoblasts express $\beta 2$-adrenergic receptors and therefore can be considered as direct effectors of the sympathetic signal transmission to HSCs [42].

STZ-induced injury of pancreas activated the SNS, which in turn secrete catecholamines. Following catecholamine signals, HSCs emerge from the niche within the bone marrow. As suggested above, this which might be indirectly mediated by osteoblasts. After migrating out of their niche, HSCs are exposed to and affected by inflammatory factors in the bloodstream and the inflamed pancreas. Notably, catecholamines themselves could affect the migration of HSCs into the pancreas. In this context, decreasing catecholamine concentration by reserpine might explain the disruption of HSCs mobilisation and reduced migration into the pancreas observed in our study.

Previously, we demonstrated that precursors of insulin-producing beta cells possess a high potential for self-renewal, and can give rise to beta cells in vitro [34]. In the present study, reserpine increased the number of multipotent beta cell progenitors and oligopotent beta cell precursors in the pancreata of $\mathrm{C} 57 \mathrm{BL} / 6$ mice. The amount of $\mathrm{Pdx} 1^{+}$beta cells of treated mice increased 2.3 fold compared to untreated diabetic mice. This effect could be explained by a reserpine-mediated reduction of the inhibitory effect of catecholamines on the VMAT2 which is known to promote late-stage differentiation of $\mathrm{Pdx}^{+}$pancreatic progenitor cells [37].

The incretin GLP-1 is released from the intestine L-cells into the blood, and targets GPCRs on beta cells which lead to an immediate insulin secretion. In addition, GLP- 1 could be involved in differentiation of beta cell precursors. We showed that during reserpine treatment the level of endogenous GLP-1 in the serum of diabetic mice increased 5.5 times compared to untreated mice. However, these concentrations are not sufficient to regenerate beta cells. We show that the number of $\mathrm{Pdx} 1^{+}$beta cells increased in diabetic mice treated with reserpine. GLP1 treatment had no influence on blood glucose levels, which remained at the level of diabetic control.

We hypothesised that reserpine-induced decrease of pancreatic inflammation followed by stimulation of beta cell precursors by GLP-1 may be more effective regarding pancreatic beta cell regeneration than reserpine monotherapy. Our data suggests that GLP-1 could potentiate the therapeutic effects of reserpine. In particular, we observed that polytherapy increased GLP-1 concentration in the serum $(9.52$ times) compared to diabetic control. Notably, the number of $\mathrm{Pdx}^{+}$ beta cells increased more than 20 times in comparison to untreated diabetic control and raised to $46 \%$ of intact control. Remarkably, the blood glucose levels as well as morphological indexes of the pancreata of animals treated with both reserpine and GLP-1 are close to intact control. However, the concentration of insulin in the serum even exceeded the healthy control group by 3.84 times. 
Citation: Skurikhin EG, Pershina OV, Ermakova NN, Ermolaeva LA, Krupin VA, et al. (2018) Polytherapy with Reserpine and Glucagon-like Peptide-1 (GLP-1) Improves the Symptoms in Streptozotocin-Induced Type-1 Diabetic Mice by Reducing Inflammation and Inducting Beta Cell Regeneration. Stem Cell Res Ther 8: 434. doi: 10.4172/2157-7633.1000434

In sum, our data suggests that the pancreatic inflammation caused by STZ is can be blocked by reserpine. This inhibition of the inflammation is necessary to prevent mobilisation of bone marrow HSCs and HPCs into the bloodstream and their migration into the pancreas. Moreover, reserpine showed strong hypoglycaemic effects, raised the concentration of insulin and GLP-1 in the serum, and increased the number of beta cells and their precursors in the diabetic pancreas.

\section{Conclusions}

Taken together, this study suggests that polytherapy with reserpine and GLP-1 could represent a new approach to pancreas regeneration (including $\mathrm{Pdx}^{+}$-cells) in diabetes. The mode of action involves reserpine-mediated reduction of inflammation and the stimulation of beta cells precursors' differentiation by GLP-1. Importantly, the efficiency of polytherapy on pancreatic beta cells regeneration is significantly higher than monotherapy with reserpine alone.

\section{Competing Interests}

The authors declare no competing financial interests.

\section{References}

1. Yang SN, Berggren PO (2005) Beta-cell CaV channel regulation in physiology and pathophysiology. Am J Physiol Endocrinol Metab 288: 16-28. [PubMed]

2. Yang SN, Berggren PO (2006) The role of voltage-gated calcium channels in pancreatic beta-cell physiology and pathophysiology. Endocr Rev 27: 621-676. [PubMed]

3. Mosna F, Sensebe L, Krampera M (2010) Human bone marrow and adipose tissue mesenchymal stem cells: a user's guide. Stem Cells Dev 19: 1449-1470. [PubMed]

4. Minami K, Seino S (2013) Current status of regeneration of pancreatic betacells. J Diabetes Investig 4: 131-141. [PubMed]

5. Gopurappilly R, Bhat V, Bhonde R (2013) Pancreatic tissue resident mesenchymal stromal cell (MSC)-like cells as a source of in vitro islet neogenesis. J Cell Biochem 114: 2240-2247. [PubMed]

6. Chung $\mathrm{CH}$, Levine $\mathrm{F}$ (2010) Adult pancreatic alpha-cells: a new source of cells for beta-cell regeneration. Rev Diabetic Stud 7: 124-131. [PubMed]

7. Habener JF, Stanojevic V (2012) Alpha-cell role in beta-cell generation and regeneration. Islets 4: 188-198. [PubMed]

8. Minami K, Okuno M, Miyawaki K, Okumachi A, Ishizaki K, et al. (2005) Lineage tracing and characterization of insulin-secreting cells generated from adult pancreatic acinar cells. Proc Natl Acad Sci U S A 102: 15116-15121. [PubMed]

9. Okuno M, Minami K, Okumachi A, Miyawaki K, Yokoi N, et al. (2007) Generation of insulin-secreting cells from pancreatic acinar cells of animal models of type 1 diabetes. Am J Physiol Endocrinol Metab 292: 158-165. [PubMed]

10. Baumann B, Salem HH, Boehm BO (2012) Anti-inflammatory therapy in type 1 diabetes. Curr Diab Rep 12: 499-509. [PubMed]

11. Alnek K, Kisand K, Heilman K, Peet A, Varik K, et al. (2015) Increased Blood Levels of Growth Factors, Proinflammatory Cytokines, and Th17 Cytokines in Patients with Newly Diagnosed Type 1 Diabetes. PloS One 10: e0142976. [PubMed]

12. Burke SJ, Stadler K, Lu D, Gleason E, Han A, et al. (2015) IL-1beta reciprocally regulates chemokine and insulin secretion in pancreatic beta-cells via NFkappaB. Am J Physiol Endocrinol Metab 309: 715-726. [PubMed]

13. Argiles JM, Lopez-Soriano J, Ortiz MA, Pou JM, Lopez-Soriano FJ (1992) Interleukin-1 and beta-cell function: more than one second messenger? Endocrine reviews 13: 515-524.

14. Farge D, Labopin M, Tyndall A, Fassas A, Mancardi GL, et al. (2010) Autologous hematopoietic stem cell transplantation for autoimmune diseases: an observational study on 12 years' experience from the European Group for Blood and Marrow Transplantation Working Party on Autoimmune Diseases. Haematologica 95: 284-292. [PubMed]
15. Ianus A, Holz GG, Theise ND, Hussain MA (2003) In vivo derivation of glucosecompetent pancreatic endocrine cells from bone marrow without evidence of cell fusion. J Clin Invest 111: 843-850. [PubMed]

16. Fiorina P, Voltarelli J, Zavazava N (2011) Immunological applications of stem cells in type 1 diabetes. Endocr Rev 32: 725-754. [PubMed]

17. Voltarelli JC, Couri CE, Stracieri AB, Oliveira MC, Moraes DA, et al. (2007) Autologous nonmyeloablative hematopoietic stem cell transplantation in newly diagnosed type 1 diabetes mellitus. JAMA 297: 1568-1576. [PubMed]

18. Hsieh MM, Kang EM, Fitzhugh CD, Link MB, Bolan CD, et al. (2009) Allogeneic hematopoietic stem-cell transplantation for sickle cell disease. New England J Med 361: 2309-2317.

19. Nagai Y, Garrett KP, Ohta S, Bahrun U, Kouro T, et al. (2006) Toll-like receptors on hematopoietic progenitor cells stimulate innate immune system replenishment. Immunity 24: 801-812. [PubMed]

20. Ueda Y, Kondo M, Kelsoe G (2005) Inflammation and the reciprocal production of granulocytes and lymphocytes in bone marrow. J Exp Med 201: 1771-1780. [PubMed]

21. Esplin BL, Shimazu T, Welner RS, Garrett KP, Nie L, et al. (2011) Chronic exposure to a TLR ligand injures hematopoietic stem cells. J Immunol 186: 5367-5375. [PubMed]

22. Kolb-Maurer A, Weissinger F, Kurzai O, Maurer M, Wilhelm M, et al. (2004) Bacterial infection of human hematopoietic stem cells induces monocytic differentiation. FEMS Immunol Med Microbiol 40: 147-153. [PubMed]

23. De Luca K, Frances-Duvert V, Asensio MJ, Ihsani R, Debien E, Taillardet M, et al. (2009) The TLR1/2 agonist PAM(3)CSK(4) instructs commitment of human hematopoietic stem cells to a myeloid cell fate. Leukemia 23: 2063-2074. [PubMed]

24. Rodriguez S, Chora A, Goumnerov B, Mumaw C, Goebel WS, et al. (2009) Dysfunctional expansion of hematopoietic stem cells and block of myeloid differentiation in lethal sepsis. Blood 114: 4064-4076. [PubMed]

25. Scumpia PO, Kelly-Scumpia KM, Delano MJ, Weinstein JS, Cuenca AG et al. (2010) Cutting edge: bacterial infection induces hematopoietic stem and progenitor cell expansion in the absence of TLR signaling. Journal of immunology (Baltimore, Md.: 1950) 184: 2247-2251. [PubMed]

26. Baldridge MT, King KY, Boles NC, Weksberg DC, Goodell MA (2010) Quiescent haematopoietic stem cells are activated by IFN-gamma in response to chronic infection. Nature 465: 793-797. [PubMed]

27. Massberg S, Schaerli P, Knezevic-Maramica I, Kollnberger M, Tubo N, et al. (2007) Immunosurveillance by hematopoietic progenitor cells trafficking through blood, lymph, and peripheral tissues. Cell 131: 994-1008. [PubMed]

28. Katayama Y, Battista M, Kao WM, Hidalgo A, Peired AJ, et al. (2006) Signals from the sympathetic nervous system regulate hematopoietic stem cell egress from bone marrow. Cell 124: 407-421. [PubMed]

29. Borden P, Houtz J, Leach SD, Kuruvilla R (2013) Sympathetic innervation during development is necessary for pancreatic islet architecture and functional maturation. Cell Rep 4: 287-301. [PubMed]

30. Langer J, Panten U, Zielmann S (1983) Effects of alpha-adrenoceptor antagonists on clonidine-induced inhibition of insulin secretion by isolated pancreatic islets. Br J Pharmacol 79: 415-420. [PubMed]

31. Nilsson T, Arkhammar P, Rorsman P, Berggren $P O(1988)$ Inhibition of glucosestimulated insulin release by alpha 2-adrenoceptor activation is parallelled by both a repolarization and a reduction in cytoplasmic free $\mathrm{Ca} 2+$ concentration. $\mathrm{J}$ Biol Chemistry 263: 1855-1860. [PubMed]

32. Sharp GW (1996) Mechanisms of inhibition of insulin release. Am J Physiol 271: 1781-1799. [PubMed]

33. Ahren B (2000) Autonomic regulation of islet hormone secretion--implications for health and disease. Diabetologia 43: 393-410. [PubMed]

34. Skurikhin EG, Ermakova NN, Khmelevskaya ES, Pershina OV, Krupin VA, et al (2014) Differentiation of pancreatic stem and progenitor beta-cells into insulin secreting cells in mice with diabetes mellitus. Bulletin of experimental biology and medicine 156: 726-730.

35. Skurikhin EG, Ermakova NN, Pershina OV, Krupin VA, Pakhomova AV, et al. (2016) Response of Hematopoietic Stem and Progenitor Cells to Reserpine in C57BL/6 Mice. Bull Exp Biol Med 160: 439-443. [PubMed] 
Citation: Skurikhin EG, Pershina OV, Ermakova NN, Ermolaeva LA, Krupin VA, et al. (2018) Polytherapy with Reserpine and Glucagon-like Peptide-1 (GLP-1) Improves the Symptoms in Streptozotocin-Induced Type-1 Diabetic Mice by Reducing Inflammation and Inducting Beta Cell Regeneration. Stem Cell Res Ther 8: 434. doi: 10.4172/2157-7633.1000434

Page 11 of 11

36. Dygai AM, Skurikhin EG, Pershina OV, Ermakova NN, Krupin VA, et al. (2016) Role of Hematopoietic Stem Cells in Inflammation of the Pancreas during Diabetes Mellitus. Bull Exp Biol Med 160: 474-479. [PubMed]

37. Sakano D, Shiraki N, Kikawa K, Yamazoe T, Kataoka M, et al. (2014) VMAT2 identified as a regulator of late-stage beta-cell differentiation. Nat Chem Biol 10: 141-148. [PubMed]

38. Calvi LM, Adams GB, Weibrecht KW, Weber JM, Olson DP, et al. (2003) Osteoblastic cells regulate the haematopoietic stem cell niche. Nature 425 841-846. [PubMed]

39. Zhang J, Niu C, Ye L, Huang H, He X, et al. (2003) Identification of the haematopoietic stem cell niche and control of the niche size. Nature 425: 836841. [PubMed]

40. Wu JY, Scadden DT, Kronenberg HM (2009) Role of the osteoblast lineage in the bone marrow hematopoietic niches. J Bone Miner Res 24: 759-764. [PubMed]

41. Lo Celso C, Fleming HE, Wu JW, Zhao CX, Miake-Lye S, et al. (2009) Liveanimal tracking of individual haematopoietic stem/progenitor cells in their niche. Nature 457: 92-96.

42. Elefteriou F, Ahn JD, Takeda S, Starbuck M, Yang X, et al. (2005) Leptin regulation of bone resorption by the sympathetic nervous system and CART. Nature 434: 514-520. [PubMed] 